\title{
EFEKTIFITAS WHATSAPP SEBAGAI MEDIA BELAJARAN DARING PADA PELAJARAN AQIDAH DI UNIVERSITAS MUHAMMADIYAH MATARAM
}

\author{
Saprun 1, Mappanyompa ${ }^{2}$, Sukarta $^{3}$ \\ 1Program Studi PGMI, 2,3Program Studi KPI, Universitas Muhammadiyah Mataram, Indonesia \\ saprunnabil5@gmail.com ${ }^{1}$ myompakaltim@gmail.com ${ }^{2} \underline{\text { nggihsilak@gmail.com }}{ }^{3}$
}

\section{INFO ARTIKEL}

\section{Riwayat Artikel:}

Diterima: 02-01-2021

Disetujui: 30-04 -2021

\section{Kata Kunci:}

Efektifitas,

whatsapp,

Belajar,

Daring.

\section{Keywords:}

Effectivess,

whatsapp,

Learning,

During.

\section{ABSTRAK}

Abstrak: Belajar daring adalah metode belajar yang menggunakan model interaktif berbasis internet dan Learning Manajemen System (LMS). Seperti menggunakan Zoom, Google Meet, Whatsapp group dan lainnya. Dan berbeda jauh dengan belajar luring, system belajar luring adalah system pembelajaran yang memerlukan tatapmuka. Whatsapp Group adalah salah satu pilihan model pembelajaran daring yang dipilih dosen pengampu mata pelajaran Aqidah di universitas Muhammadiyah Mataram. Maka penting untuk menelisik bagaimana efektifitas belajar daring melalui Whatsapp. Peneliti melakukan penelitian lapangan dengan pendekatan kualitatif deskriptif pada jurusan Ilmu Pemerintahan Semester 1 (satu). Hasilnya menunjukkan bahwa pembelajaran daring melalui Whatsapp pada mahasiswa sangat efektif dan sebagai solusi belajar dimasa pandemic Covid-19. Hal ini terlihat dari persentase sample yang diuji sebanyak 45 orang, dengan hasil 42 responden menyatakan sangat efektif dengan perhitungan $42 / 45 \times 100 \%=93,3 \%$ dan 3 orang responden menyatakan kurang efektif dengan perhitungan $3 / 45 \times 100 \%=6,6 \%$.

\begin{abstract}
Online learning is a learning method that uses an interactive model based on the internet and the Learning Management System (LMS). Like using Zoom, Google Meet, Whatsapp groups, and more. And in contrast to offline learning, the offline learning system is a learning system that requires face-to-face. Whatsapp Group is one of the choices of online learning models chosen by lecturers who teach Aqidah subjects at muhammadiyah university Mataram. So it is important to explore how effective online learning is through Whatsapp. Researchers conducted field research with a descriptive qualitative approach in the department of Government Science Semester 1 (one). The results show that online learning through Whatsapp in students is very effective and as a learning solution during the Covid-19 pandemic. This can be seen from the percentage of samples tested as many as 45 people, with the results of 42 respondents declared very effective with the calculation of $42 / 45 \times 100 \%=93.3 \%$ and 3 respondents declared less effective with the calculation of $3 / 45 \times 100 \%=6.6 \%$.
\end{abstract}

\section{A. LATAR BELAKANG}

Perkembangan Pandemi Covid-19 di dunia yang semakin tidak terkontrol membuat berbagai usaha dilakukan untuk memutus matarantai penularan Covid-19 memaksa berbagai aspek kehidupan berubah drastis. Pemerintah dengan segala kemampuan dan dengan pertimbangan yang besar untuk kebaikan bersa mamemutuskan work from home. Belajar pun diwajibkan belajar dengan sistem daring. Hal ini bertujuan untuk memutus penularan yang meluas akibat interaksi yang masif.

Berbagai macam langkah pencegahan diupayakan diantaranya Physical distancing menjadi salah satu strategi jitu digencarkan pemerintah dengan menugaskan aparatur Negara sebagai grada terdepan untuk menyelamatkan bangsa dan Negara dari virus covid-19 dengan harapan memutus rantai penularan penyakit yang mematikan ini. Perubahan yang dipaksa oleh Covid-19 begitu cepat. Menyebabkan persiapan untuk menghadapi berbagai perubahan menjadi tidak maksimal, didunia usaha misalnya banyak mengalami kebangkrutan bahkan jatuh berguguran satu persatu, akibat hal ini terlihat dari terjadinya pemutusan hubungan kerja yang besar besaran (Aldila, 2020) (Safuroh, n.d.). Hal yang serupa juga dirasa oleh dunia pendidikan. Kesiapan untukbelajar daring (online) yang ditetapkan oleh pemerintah nyaris tidak ada. Perguruan tinggi dalam hal ini dosen dituntut berusaha mengkreasikan belajar agar tetap berjalan meski tidak dengan bertatap muka langsung. Maka dikenallah istilah baru dalam dunia pembelajaran yaitu daring. Ada banyak media yang digunakan untuk belajar daring. Berbagai platform sudah lama menyediakan jasa ini (Mappanyompa 
\& Ali, 2017). Diantaranya Google Clasroom, Rumh Belajar, Edmodo, Ruang Guru, Zenius, Google Suite for Education, Microsoft Office 365 for Education, Sekolahmu, Kelas Pintar. Inilah yang disebutsebagai platform microbloging (Basori, 2013). Didalam proses pembelajaran dengan system yang baru dirasa sangat menantang dan sangat membantu dan mudah untuk menyesuaikan diri karena dosen dan mahasiswa sudah tidak asing dengan Gadget. Hal baru ini memberkan dampak positif pada proses pembelajaran (Wisudawati et al., 2020). Namun, sudah barang tentu dosen dan mahasiswa dituntut untuk samasama aktif memaksimalkan whatsapp group sebagai media pilihan untuk belajar dimasa pandemi Covid-19. Apalagi mahasiswa dengan berbagai latar belakang tingkat pengahasilan sudah barangtentu berdampak besar bagi perekonomian keluarga terutama yang berada di daerah-daerah terpencil dan pedalaman, Disinilah problem itu, tidak adawaktu lagi untuk menundanunda proses pembelajaran, belajar harus tetap berjalan. Covid-19 sudah tiba-tiba datang dan memaksa semuanya untuk tetap di rumah. Maka dosen harusbisa menggunakan berbagai media yang familiar digunakan mahasiswa. Harapannya tidak mempersulit untuk mahasiswa dan tidak memberatka nprekonomian orang tua mahasiswa, terlebih lagi yang terdampak langsung dengan Covid-19.

Kemajuan teknologi sangatlah mempengaruhi dalam kehidupan kita, terlebih lagi dalam media komunikasi yang memudahkan kita untuk memberikan informasi. Hal ini berkembang sangat cepat dari tahun ke tahun mengalami kemajuan sangat pesat. Salah satunya penggunaan media telepon yang telah mengalami proses peralihan dimana saat ini kecenderungan masyarakat ingin memiliki media yang serefisien dari segi bentuk dan waktu. Maka penggunaan handphone atau telepon genggam adalah solusi dari hasil inovasi terkemuka yang kita temui pada masa sekarang.

Dengan penggunaan handphone ini maka aplikasi serta fitur ikut mengalami peralihan yang tetap menjaga fungsi utama dari media tersebut sebagai sarana komunikasi. Banyak sekali kegunaan handphone ini dalam membantu kita menyebarkan informasi baik untuk pribadi, pekerjaan ataupun untuk keluarga. Salah satu pembahasan yang menarik bagi peneliti untuk membahasnya adalah aplikasi whatsapp. Dimana, aplikasi tersebut selain bisa berbagi informasi tetapi juga bisa mengirim gambar berupa foto-foto bahkan juga dapat merekam suara serta video.
Sehingga hal ini merupakan kemudahan dan kelancaran dalam berkomunikasi.

Tentu saja kegunaan ini ditempatkan sesuai dengan fungsinya dan keperluannya tanpa mengurangi nilai fungsi handphone itu sendriri. Tetapi sebaliknya sangat membantu serta mempermudah dalam berkomunikasi. Harga handphone saat ini pun bervariasi mulai dari harga yang terjangkau bagi kalangan ekonomi ke bawah bahkan sampai yang termahal juga ada. Harga menentukan kualitas, merek, serta kelengkapan fitur dan fasilitas tiap handphone berbeda-beda. Dahulu handphone atau telepon genggam merupakan barang mewah karena hanya orangorang tertentu dapat memilikinya akan tetapi, berbeda dengan masa sekarang handphone merupakan kebutuhan yang tidak bisa lepas sehingga hargapun bukan tolak ukur melainkan pembedaan kualitasnya saja.

Perbedaan kebutuhan berkomunikasi dari masa ke masa mengalami perkembangan, mengingat masyarakat menginginkan komunikasi yang lebih efisien dan menghemat waktu maka terlahirlah smarthphone. Pembedaan dengan handphone terdahulu yakni handphone hanya berfungsi untuk telepon yang lebih menonjolkan sisi kekuatan audio bedahalnya dengan smartphone tetap tidak mengurangi fungsi sebagai media komunikasi hanya saja memiliki lebih banyak kelebihannya, diantaranya selain untuk media audio tetapi juga sebagai kekuatan audio visual. Dengan adanya kamera pada handphone dapat memotret gambar serta record video dan dapat mengirim gambar serta video tersebut kepada orang lain bahkan ke orang banyak sekalipun (group). Kecanggihan ini memiliki dampak yang besar dalam kehidupan masyarakat, bahkan dalam dunia pendidikan sekalipun memiliki fungsi yang cukup besar bagi mahasiswa khususnya.

Bila penempatan kecanggihan teknologi media elektornik seperti smarthphone dapat diposisikan sebagai sarana media yang memiliki kekuatan positif maka memberi kemudahan dalam dunia pembelajaran. Sayangnya, hal ini banyak yang tidak menyadari akan penempatan kecanggihan media elektronik tersebut. Padahal, bila ini direalisasikan dalam dunia pembelajaran maka memudahkan kita untuk menjadikan smartphone sebagai teman berbagi informasi dan pembelajaran.

Dengan melihat kondisi Covid-19 yang semakin menghawatirkan serta adanya kemudahan teknologi di zaman ini maka merupakan suatu keharusan bagi tenaga pendidik 
dan peserta didik untuk mengambil Langkah cepat sebagai solusi dalam dunia Pendidikan.

Penggunaan WhatsApp Groups sebagai media belajar sangat dirasa efektif baik bagi dosen dan mahasiswa, terutama bagi mahasiswa yang memiliki keterbatasan prekonomian, maka dalam hal ini dosen harus bijak menentukan pilihan media pembelajaran agar semua mahasiswa baik yang berada di kota maupun di desa dan pelosok tetap bias mengikuti pembelajaran dengan baik. Pada level pendidikan tinggi WhatsApp hanya salah satu media alternative dalam proses pembelajaran dan masih banyak lagi media pembelajaran yang ada. Hal ini menarik bagi peneliti untuk meneliti bagaimana efektifitas belajar daring melalui WhatsApp ini. Peneliti akan mengeksplore bagaimana system belajar melalui media Whatsapp ini, khususnya pada perguruantinggi. Kendala-kendala apa yang dihadapi dan bagaimana juga respon mahasiswa.

\section{B. METODE PENELITIAN}

Penelitian ini adalah penelitian lapangan (field research) yang berusaha melihat realitas praktis penggunaan WhatsApp sebagai media belajar. Penelitian ini termasuk kualitatif deskriptif maka peneliti akan memanfaatkan data-data kualitatif kemudian dijabarkan secara deskriptif. Peneliti melakukan observasi, yang mana observasi ini merupakan sebuah teknik yang dilakukan lewat pengamatan langsung. Peneliti melakukan pengamatan di tempat objek penelitian untuk diamati menggunakan pancaindra. Peneliti dalam hal ini diposisikan sebagai pengamat atau orang luar.

Dalam mengumpulkan data menggunakan observasi, peneliti dapat menggunakan catatan maupun rekaman. Observasi dapat bersifat partisipatoris, yaitu ketika peneliti turut bergabung dan melakukan aktivitas bersama objek pengamatannya.

wawancara merupakan salah satu metode yang paling banyak digunakan para peneliti untuk mengumpulkan informasi dan data. Dengan wawancara, seseorang bisa mendapatkan berbagai macam informasi yang dibutuhkan. Agar bisa mendapatkan informasi yang dibutuhkan, pewawancara harus mengetahui langkah-langkah, etika, dan jenis wawancara.

Secara umum, wawancara atau interview adalah tanya jawab antara dua pihak yaitu pewawancara dan narasumber untuk memperoleh pendapat, keterangan, dan data. Biasanya, wawancara digunakan untuk mendapatkan informasi yang berhubungan dengan fakta, kepercayaan, perasaan, dan keinginan yang diperlukan untuk memenuhi tujuan penelitian.

Wawancara sendiri dibedakan menjadi beberapa jenis, yaitu berdasarkan cara pelaksanaan, jumlah narasumber, dan keterbukaan informasi. Di mana beberapa jenis wawancara tersebut memiliki cirinya masing-masing.

dan studi dokumen untuk mendapatkan data. Observasi dimana peneliti terlibat secara langsung di dalam proses belajar daring diuniversitas Muhammadiyah Mataram. Sedang interview dilakukan kepada mahasiswa langsung untuk mendalami sejauh mana proses pembelajaran dengan daring telah berjalan.

\section{HASIL DAN PEMBAHASAN}

Pembelajaran daring pada tingkat perguruan tinggi adalah sebuah pilihan yang tepat dimasa pandemic Covid-19. Pandemi Covid-19 yang menyebar begitu cepat hingga hampirk eseluruh negara di dunia memaksa pemerintah untuk menutup sekolah-sekolah dan perguruan tinggi negri dan swasta yang ada diseluhruh tanah air. Mulai tanggal 16 Maret 2020 Pemerintah meminta sekolah-sekolah di tutup (Purnamasari, 2020). Meskipun sesungguhnya kesiapan untuk belajar daring nyaris belum ada. Banyak hal yang mendukung pembelajaran daring ini misalnya jaringan internet yang cukup merata, akses internet yang relative murah dan bisa dibelid imanapun, bahkan ada layanan dari desa menyediakan Wi-Fi geratisan untuk menunjang pembelajaran daring yang bebas diakses oleh semua pelajar dan mahasiswa di masing-masing desa di setiap kecamatan, terlebih lagi di perkotaan sudah pasti akan lebih mudah untuk mengakses jaringan internet.

Ditambah berbagai provider penyedia jasa internet yang bersaing dengan menawarkan harga paket dari yang termurah sampai yang paling tinggi, walaupun terdapat sedikit kendala-kendala untuk mengakses layanan internet seperti yang dialami mahasiswa-mahasiswa yang berada di pelosok-pelosok pedesaan seperti di Sumbawa, bima, dan Nusa Tenggara Timur. Namun pihak universitas dan mahasiwa sudahjauh-jauh hari dihimbau untuk mempersiapkan diri untuk menghadapi kemungkinan terberat daridampak Covid-19, maka sebagai wujud kepedulan pihak universitas kepada para mahasiswa sebelum pulang kampong pihak universitas memberikan keringanan dengan cara mensubsidi kuwota pulsa internet disetiap semester untuk kelancaran proses pembelajaran.Whatsapp Group adalah 
sarana pembelajaran yang paling efektif digunakan dosen dan mahasiswa dalam proses belajar daring bahkan menjadi sarana pilihan utama di masa pandemi Covid-19,

Media pembelajaran adalah alat atau bentuk stimulus yang berfungsi untuk menyampaikan pesan pembelajaran. Bentukbentuk stimulus bisa dipergunakan sebagai media diantaranya adalah hubungan atau interaksi manusia, realia, gambar bergerak atau tidak, tulisan, dan suara yang direkam. Kelima bentuk stimulus ini akan membantu peserta didik. Namun demikian, tidaklah mudah mendapatkan kelima bentuk ini dalam satu waktu atau tempat. Media pembelajaran yang baik harus memenuhi beberapa syarat. Media pembelajaran harus meningkatkan motivasi peserta didik. Penggunaan media mempunyai tujuan memberikan motivasi kepada peserta didik. Selain itu media juga harus merangsang peserta didik mengingat apa yang sudah dipelajari selain memberikan rangsangan belajar baru. Media yang baik juga akan mengaktifkan peserta didik dalam memberikan tanggapan, umpan balik dan juga mendorong peserta didik untuk melakukan prkatik-praktik dengan benar (Rusman, 2013: 61).

Ada lima jenis media yang dapat digunakan dalam pembelajaran, yaitu Rusman. 2013: 62) : 1 . Media Visual, adalah media yang hanya dapat dilihat dengan menggunakan indra penglihatan yang terdiri dari atas media yang diproyeksikan dan media yang tidak dapat diproyeksikan yang biasanya berupa gambar diam atau gambar bergerak. 2. Media Audio, yaitu media yang mengandung pesan dalam bentuk auditif yang dapat merangsang pikiran, perasaan, perhatian, dan kemauan para peserta didik untuk mempelajari bahan ajar. Contoh dari media audio ini adalah program kaset suara dan program radio.

3. Media Audio-Visual, yaitu media yang merupakan kombinasi audio dan visual atau biasa disebut media pandang-dengar. Contoh dari media audio-visual adalah program video /televisi dan program slide suara (sound slide). 4. Kelompok Media Penyaji, media ini sebagaimana diungkapkan Donald T.Tosti dan John R.Ball dikelompokkan ke dalam tujuh jenis, yaitu : (a) kelompok kesatu ; grafis, bahan cetak, dan gambar diam, (b) kelompok kedua ; media proyeksi diam, (c) kelompok ketiga ; media audio, (d) kelompok keempat ; media audio, (e) kelompok kelima ; media gambar hidup/film, (f) kelompok keenam ; media televise, dan (g) kelompok ketujuh ; multimedia. 5. Media objek dan media interaktif berbasis komputer. Media objek merupakan media tiga dimensi yang menyampaikan informasi tidak dalam bentuk penyajian, melainkan melalui ciri fisiknya sendiri, seperti ukurannya, bentuknya, beratnya, susunannya, warnanya, fungsinya, dan sebagainya.

Berdasarkan wawancara yang peneliti dapatkan di lapangan maka penggunaan whatsapp memiliki keterkaitan bukan hanya dalam dunia komunikasi semata tetapi juga berkaitan dengan kecanggihan teknologi dan system pembelajaran khususnya dalam dunia perguruan tinggi. Dari hasil wawancara dengan beberapa mahasiswa yang menggunakan whatsapp merasakan kegunaannya selain untuk chat atau obrolan dengan sesame teman tetapi juga efektif bila digunakan sebagai sarana pembelajaran sebagai sarana pemberian materi ataupun pengumpulan tugas melalui aplikasi di smartphone mereka, selain itu whatsapp group tidak membutuhkan kuota yang besars ehingga berbiaya rendah dan dengan mudah bisa mengirimkan gambar, voice note hingga vidio. Whatsapp juga aplikasi dengan jumlah pengguna yang sangat besar dan sangat mudah cara pemakaiannya dibandingkan dengan aplikasi yang lain, (Pertiwi, 2020). Di Indonesia sendiritahun 2019 dilaporkan 143 Juta orang menggunakan WhatsApp (Wardani, 2019). Jadilah WhatsApp sebagaiaplikasi yang paling banyak digunakan terkait dengan komunikasi dosen dan mahasiswa selama Pandemi Covid-19 ini, seperti yang diungkapkan oleh Alif Hawarakelas 1 A ilmu Pemerintahan mengatakan bahwa memakai whatsapp sangat memudahkan karena disaat menerima pesan berbentuk gambar tidak perlu harus save gambar tersebut tetapi secara langsung sudah tersimpan dengan sendirinya fiturini yang tidak dimiliki oleh aplikasi lainnya (wawancara 7 April 2021).

Hal yang sama juga diungkapkan oleh $\mathrm{M}$. Mijrad Aslam mengatakan bahwa bila dibandingkan dengan fitur lain harus membuka dulu isi pesannya berupa gambar tetap berbeda dengan whatsapp tanpa perlu kita membuka filenya secara langsung sudah tersimpan dengan sendirinya. Ini yang tidakdimilikifitur lain. (wawancara pada tanggal 17 April 2021)

Kemudahan yang lain juga dirasakan oleh Siti Rahmawati manyatakan bila ingin berkomunikasi dengan seseorang kita hanya butuh nomor handphone saja bila tersimpan nomornya tidak harus menginstal program-program yang lain beda halnya dengan aplikasi yang lain seperti zoom dan yang lainnya. (wawancara pada tanggal 21 April 2021)

Hal serupa juga dirasakan oleh Cahya Radita Pratama, mengatakan bahwa terkadang dalam perkuliahan bila ada dosen yang 
memberikan tugas dan kurang memahaminya bisa menjadi bahan diskusi dengan teman tentang tugas tersebut secara tidak langsung memudahkan untuk media komunikasi dengan topic belajar atau diskusi materi kuliah. Dari kemudahan komunikasi ini sangat membantu dalam belajar karena kurangnya pemahaman materi kuliah dapat didiskusikan dengan teman atau bertanya langsung dengan dosen yang bersangkutan bila memungkinkan. (wawancara pada tanggal 27 April 2021).

$\begin{array}{llr}\text { Ketika } & \text { peneliti menelisik efektifitas } \\ \text { penggunaan } & \text { Whatsapp sebagai media }\end{array}$
pembelajaran pada mahasiswa Kelas 1 A Ilmu Pemerintahan dengan jumlah 45 mahasiswa, maka mayoritas mahasiswa menyimpulkan yakni sebanyak 42 atau $42 / 45 \times 100=93 \%$ mahasiwa menyatakan sangat efektif dan sebanyak 3 atau $3 / 45 \times 100=6,6 \%$ mahasiswa memberikan pernyataan kurang efektif.

Maka hal ini menjadi tolakukur peneliti dalam menilai keefektifan whatsapp group sebagai solusi belajar mahasiswa di masa pandemi Covid19 karena mahasiswa dituntut aktif didalam proses pembelajaran, dan hal ini sejalan dengan wacana mentri pendidikan dan kebudayaan Nadiem Anwar Makarim yaitu kampus merdeka belajar, yaitu memberikan kebebasan kepada mahasiswa untuk memilih bidang yang mereka sukai dengan tujuan memberikan keluasan kepada mahasiswa untuk belajar di luar kampus, sehingga dosen sudah tidak lagi menjadi sumber utama dalam belajar. Hal ini juga sangat membantu bagi kemandirian mahasiswa didalam menggali semua potensi yang dimiliki, serta memberikan rasa kepercayaan dan tanggungjawab sebagais seorang mahasiswa dalam mencari bakat dan kemampuan diri.

Maka tidak menutup kemungkinan model pembelajaran yang akan dilakukan disemua jenjang pendidikan dari tingkat sekolah dasar sampai perguruan tinggi kedepan akan menerapkan sistem pembelajaran jarak jauh atau istilah yang sering kita dengar dengan belajar dari rumah (BDR).

Metode Belajar dari rumah (BDR) sendiri ada dua, yaitu Pembelajaran Jarak Jauh Dalam Jaringan (PJJ Daring) dan PPJ Luar Jaringan (Luring). PJJ Daring secara khusus menggabungkan teknologi elektronik dan teknologi berbasis internet, sementara PJJ Luring dapat dilakukan melalui siaran televisi, radio, modul belajar mandiri, bahan cetak maupun media belajar dari benda di lingkungan sekitar.

Karena peluang pendidikan masa depan yang terbentuk dari kondisi pandemi Covid-19 ini bisa saja tetap diterapkan melihat situasi perkebangan Covid-19 yang tidak kunjung mereda bahkan semakin mengkhawatirkan.

Indonesia punya tantangan besar dalam penanganan Covid-19. Tantangan Pembelajaran Persebaran virus Corona yang massif di berbagai negara, memaksa kita untuk melihat kenyataan bahwa dunia sedang berubah. Kita bisa melihat bagaimana perubahan-perubahan di bidang teknologi, ekonomi, politik hingga pendidikan di tengah krisis akibat Covid-19. Perubahan itu mengharuskan kita untuk bersiap diri, merespon dengan sikap dan tindakan sekaligus selalu belajar hal-hal baru. Indonesia tidak sendiri dalam mencari solusi bagi peserta didik agar tetap belajar dan terpenuhi hak pendidikannya. Sampai 1 April 2020, UNESCO mencatat setidaknya 1,5 milyar anak usia sekolah yang terdamapk Covid 19 di 188 negara termasuk 60 jutaan diantaranya ada di negara kita. Semua negara terdampak telah berupaya membuat kebijakan terbaiknya dalam menjaga kelanggengan layanan pendidkan. Indonesia juga menghadapi beberapa tantangan nyata yang harus segera dicarikan solusinya: (1) ketimpangan teknologi antara sekolah di kota besar dan daerah, (2) keterbatasan kompetensi pendidk dalam pemanfaatan aplikasi pembelajaran, (3) keterbatasan sumberdaya untuk pemanfaatan teknologi Pendidikan seperti internet dan kuota

Keterbatasan yang dimiliki Lembagalembaga Pendidikan dan tenaga pendidik tidak menjadi alasan untuk tetap semangat mendidik dan berinofasi dalam dunia Pendidikan.

\section{SIMPULAN}

Penggunaan Whatsapp sebagai media pembelajaran daring sangat efektif dalam mencapai tujuan pembelajaran baik bagi mahasiswa dan dosen. Hal ini disebabkan berbagai faktor pendukung, diantaranya persiapan dan kesiapan dari dosen dan mahasiswa yang cukup matang, keluasan ketersediaan waktu dan ruang pembelajaran sehingga mahasiswa lebih merasa leluasa, ketersedian sarana belajar seperti sinyal internet dan penguasaan media pembelajaran baik dari dosen dan mahasiswa sangat memumpuni, Kapasitas dosen dan kemampuan mahasiswa yang memadai menjadi sumber pendukung dalam kelancaran proses pembelajaran dengan system daring, sehingga kedepan dirasa perlu upaya serius dari semua pihak untuk membangun system pembelajaran daring yang semakin efektif dan inopatif. Hingga tidak lagi kita dengar system pembelajaran daring terkendala akibat kurangnya 
kemampuan dosen dan mahasiswa dalam penguasaan sarana pembelajaran, dan tidak lagi kita mendengarkan pembelajaran daring sebagai alternative dalam sebuah system pembelajaran, namun sudah menjadi sebuah keharusan dan solusi tepat didalam menjawab tantangan zaman kedepan.

\section{DAFTAR RUJUKAN}

Abdurrahman. (2019). Upaya Meningkatkan Perkembangan Nilai Agama dan Moral Melalui Metode Keteladanan pada Anak Usia Dini. JurnalRealita, 4, 700-705.

Aldila, N. (2020, Mei). 25 Juta Orang DiperkirakanKehilanganPekerjaanAkibat Covid-19. https://kabar24.bisnis.com/read/2020051 9/ 15/1242794/25-juta-orangdiperkirakankehilangan-pekerjaan-akibatcovid-19

Arhando, P. (2019, September 26). Ternyata 60\% Orang Indonesia Belum Nikmati Internet. https://lifepal.co.id/media/penggunaanint ernet-masih-timpang-di-indonesiainifaktanya/

Atsani, L. (2020). Transformasi Media Pembelajaran pada Masa Pandemi Covid19. $1,44-45$.

Mappanyompa, \& Ali, M. (2017). Urgensi Pembelajaran Bahasa Arab Berbasis Lingkungan Dan Permainan Untuk Meningkatan Kualitas Baca Tulis Al- Qur'an. 2(2), 54-80.

Efektivitas WhatsApp sebagai Media Belajar Daring - MirzonDaheri, Juliana, Deriwanto, Ahmad DibulAmda DOI: 10.31004/basicedu.v4i4.445

PANDEMI VIRUS CORONA. Muallimuna: Jurnal Madrasah Ibtidaiyah, 5(2), 21. https://doi.org/10.31602/muallimuna.v5i 2. 2950

CNN, T. (2019, February 3). Kecepatan Internet Indonesia ke-2 Terbawahdari 45 Negara. https://www.cnnindonesia.com/teknologi /20190201152441-185-365734/ ecepataninternet- indonesia-ke-2terbawah-dari-45negara

CNN, T. (2020, March 14). AniesTutupSekolahDua Pekan dan TundaUjian Nasional di DKI. https://www.cnnindonesia.com/nasional/ 2 0200314131859-20-483393/aniestutupsekolah-dua-pekan-dan-tundaujiannasional-di-dki

Daheri, M., \&Warsah, I. (2019). Akhlak: RelasiantaraSekolah dan Keluarga. At-
Turats : JurnalPemikiran Pendidikan Islam, 13, 3-20.

Damanik, C. (2013, Mei). Jarak IdealismeKurikulum dan Realitas. https://edukasi.kompas.com/read/2013/0 $5 /$

06/11252265/jarak.idealisme.kurikulum.d an.realitas?page $=$ all

Dewi, W. A. F. (2020). DAMPAK COVID-19 TERHADAP IMPLEMENTASI PEMBELAJARAN DARING DI SEKOLAH DASAR. 2(1), 7.

Dikdas, D. (2020, April 10). KemendikbudHadirkan Program 'Belajar Dari Rumah' di TVRI. http://pgdikdas.kemdikbud.go.id/readnew s/kemendikbud-hadirkan-programbelajardari-rumah-di-tvri

Harususilo, Y. (2020, March 17). Belajar di Rumah, Cara UnikSekolah: KirimTugasLewat WA Orang Tua, ApaLagi. https://edukasi.kompas.com/read/2020/0 3/ 17/160835971/belajar-di-rumah-carauniksekolah-kirim-tugas-lewat-waorangtuaapa-lagi?page $=$ all

Herliandry, L. D., Suban, M. E., \&Kuswanto, H. (2020). Pembelajaran Pada Masa Pandemi Covid-19. 22(1), 6.

Kurniati, E., Nur Alfaeni, D. K., \&Andriani, F. (2020). Analisis Peran Orang TuadalamMendampingi Anak di Masa Pandemi Covid-19. JurnalObsesi:Jurnal Pendidikan Anak Usia Dini, 5(1), 241. https://doi.org/10.31004/obsesi.v5i1.541

Laoli, N. (2019, March 26). MenkominfoAkui Pembangunan Jaringan Internet di Indonesia Belum Merata. https://regional.kontan.co.id/news/menko minfo-akui-pembangunan-

jaringaninternet-di-indonesia-belummerata

Lestari, S., Sar"an, \&Budiman, fajar. (2020). PengaruhLiterasiAkidahAkhlak Dan TemanSebayaTerhadapAkhlakSiswa. Jurnal Al-Karim: Jurnal Pendidikan, Psikologi Dan Studi Islam, 5, 107-124.

Nufus, W. (2020, March 14). Anies: PenutupanSekolahadalahKewenangan Daerah, SudahKoordinasikeKemendikbud. https://news.detik.com/berita/d4938973/ anies-penutupan- sekolahkewenangandaerah-sudah-koordinasi-kekemendikbud. 